\title{
飽和含水土壤内の凍土・温度予測 一土壤の凍結や融解現象を含む数值解析一
}

\author{
草野剛嗣 ${ }^{1}$, 逢坂昭治 ${ }^{1}$, 相馬啓 ${ }^{2}$, 堀井清之 ${ }^{3}$ \\ 1 徳島大学大学院・ソシオテクノサイエンス研究部 \\ 2 ケミカルグラウト株式会社・技術開発部 \\ 3 白百合女子大学・文学部
}

\begin{abstract}
概
要

著者らはこれまでに飽和含水土壤の凍結速度に及ぼす土壤含水率, 土壤の初期温度, 凍結管冷却温度および 土畩物性值などの影響について実験的に検討してきた ${ }^{1)}$ 。本論文では凍結や融解を含む土䁃内の温度分布予 測のための数值モデルを提案し, 数值子測結果と模擬土壤を用いた実験データや実際の地盤凍結工法で測定 された測温データと比較を行いモデルの妥当性を検証した。その結果，このモデルでは冷熱源または温熱源が 複数存在する場合や土壤の熱物性值が局所的に変化する場合, さらに地下水流が存在する系についても解析 が可能であることが明らかになった。また，土壤の初期含水率，初期温度および凍結管冷却温度が凍結現象 に及ぼす影響について検討した結果，特に土壤の初期含水率や冷却温度は凍結速度に大きな影響を与えるこ とがわかり，また凍結が進むと各凍結管から成長した凍土同士が連結することで未凍結領域の冷却速度が低 下し，その後の凍土の発達に強く影響することが明らかとなった。
\end{abstract}

キーワード：数值解析, 凍土, 熱, 飽和土, 含水率, 凍結速度, 冷却温度, 土壤初期温度

\section{1.はじめに}

近年, 都市部だけでなく郊外や山間部においても地下空 間の利用が急速に増大しつつあり, 地下鉄, 道路, 上下水 道, 暗渠水路などの各種トンネルが数多く存在する。今後 は大都市部を中心にこれらの地下利用の大規模 $\cdot$ 大深度化 が進み, 地下空間の利用は一層拡大するものと考えられる。 一般に地下土木工事では薬液注入による強化地盤や地盤凍 結工法による人工凍土が工事中の耐力・止水壁に用いられ るが, 今日の環境問題, 土壌污染に対する意識の高まりから, 低公害でクリーンな工法である地盤凍結工法が注目されてい る。従来, 地盤凍結工法は旧来工法では施工が難しい軟 弱地盤における仮設工法として始められたが, シールド工法 の普及に伴いシールドマシン発進部, 到達部や急曲がり部な どで多く使われるようになり, 現在では, この工法の日本国 内に打ける施工実績は数多い ${ }^{2)}$ 。

このように地盤凍結工法は広範囲に用いられつつある が, 従来工法に比べて工費が若干割高で効率的な凍結が必 要とされる上, 土壤を凍結させることによって生じる凍上 が近接する地下構造物や地上建物に影響を及ぼす短所が 存在するため, 凍土造成範囲の予測が不可欠である。また, 従来では人工凍土は施工後, 自然解凍されるものがほとん どであったが, 現在では自然解凍に伴う長期の地盤変動を 避けるために強制解凍 (融解) を行う事例も増えつつあり, さらには地盤凍結・解凍工法技術を一部利用したメタンハ イドレードの採掘法 (加熱法) も実用化の一歩手前にさし かかっており, 凍結だけでなく融解現象を含む土壤内の正 確な温度場および凍土の正確な予測が必要とされている。
土壤の凍結現象は自然界や工業上広く見られる現象の ため ${ }^{3)}$, 土壤の凍結または融解を伴う熱伝達問題に関する 研究は以前より多くなされてきており，1960年代よりす でに地盤凍結工法に利用する目的で研究が行われてきた (たとえば文献 4)，これら旧来の予測モデルは実験に基づ くものや, 単純な系での解析的モデルに基づくものであ り, 局所的に土壤の物性值が変化する場合や熱源・冷熱源 が複数存在する場合などの複雑な系に対しては適用でき なかった。近年ではこれらの欠点を補べく, 熱伝達現象 を含まない土壤内の移流拡散現象に関する優れたモデル や ${ }^{4)}$, 含水土畩の凍結を取り扱ういくつかのモデルも考案 され ${ }^{5(0) 7)}$ ，コンピュータの処理能力の向上とともに FEM 解析技術も取り入れられてきている。特に液化天然ガス （LNG）地下貯蔵タンク周りには人工凍土が形成され，こ の土壤の凍結に伴う凍上やタンクへの圧力変化が問題と なるため, 含水土壤の凍結現象と凍上, 地盤変位, 凍結土 圧などを併せて解析可能なモデルが開発されている ${ }^{819) 。 ~}$

これらの FEM を用いたモデルでは FEMの利点から系 の幾何形状が複雑な場合にも対処可能で温度と構造計算 を同時に解くことができるものの, 物理系から解析系への モデル化や解析プログラムの作成がやや複雑であり, 土壤 間隙水の対流を考慮する場合や間隙水が真水ではない場 合への拡張は複雑で困難を伴う。したがって, 施工現場で 実際の測温温度に基づいて直ちに修正再計算が手軽にで きるとは言い難い。

そこで本論文では, 系の幾何形状が複雑で場合や, 局所 的に土壤の物性值が変化する場合, 熱源. 冷熱源が複数存 
在する場合, さらには凍結後の再融解を含むような複雑な 系にも適用可能で取り扱いが比較的簡易な飽和含水土壌 内の凍結や融解現象を含む熱・物質移動数值モデルの構築 を行った。このモデルの原型は著者の一人が元来. 蓄熱槽 内の熱・物質移動現象を解析するために提案したモデルで あり，固一液相変化を伴う純水の熱伝達問題だけでなく ${ }^{10)}$, 相変化を含まない水の密度逆転による影響 ${ }^{11)}$ や多成分 系水溶液の凝固現象 $\left.{ }^{12}\right)$ なども精度よく解析することが可 能である。したがってこの数值モデルを用いることで土壌 の間隙水の対流の影響（地下水流の影響, 带水層に打ける 自然対流の影響)，塩水や多成分を含んだ土塞の凍結・融 解などが解析可能になり，また，このモデルを FDM 法に 基づく各種の数值計算解法に適用すれば, 物理系から解析 系へのモデル化やプログラム化が比較的容易であり,小規 模の計算機資源で解析が可能となる。まず本研究では土䁃 内の凍結·融解現象に適用可能なように修正されたこのモ デルによる計算結果を模擬土壤を用いた実験や実際の地 盤凍結工法で測定された温度データと比較・検討すること によりモデルの妥当性を検証し,さらに, 含水率や土壤の 熱物性值が土壤の凍結に及ぼす影響についても系統的に 調べた。

\section{2. 数值モデルと支配方程式}

凍結または融解を伴う飽和含水土壤の熱・物質移動現 象は, 数学的には固一液相界面が時間とともに移動する 移動境界問題であり, このような問題では Neumann 問題 やStefan 問題のような単純な条件の場合を除いては解析 解を得ることは難しく, 数值解を得るための数値モデルが 必要となる。このモデルには, 熱伝導のみを考慮した式 を用いる固相（凍土）と移流による効果を考慮した式を 用いる液相（凍土以外）で個々に解き, 固一液相界面で のエネルギバランスの式によって凍土境界面の位置抢よ び移動を決定する, Multi-domain model と連続体のモデル を用いて固相・液相に関係なく同一の式で解く, Single-

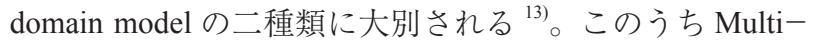
domain model は固 - 液界面位置の正確さや界面近傍での 現象の分解能は優れているものの, 複数の熱源・冷熱源が 存在する場合には座標系の取り扱いが複雑になり, 界面形 状が複雑になるにつれて座標変換が不可能になり計算が できなくなる。一方, Single-domain model では固相, 液 相および固体粒子が含む系を単一の式のセットで表し, 式 を解くため, 界面位置が厳密に求まらない（液相の存在 割合から近似される）ものの, 全体を単一の式で表すこと により界面での特別な取り扱いを必要とせず, 結果として 界面が複雑な場合でも解析が可能である。したがって本研 究では, 熱源・冷熱源位置が不規則のような系の幾何形状 が複雑な場合や凍結·融解界面位置が複雑になることが予 想される問題に対しても対処可能なように Single-domain model に基づいて数值モデルの導出を行った。

以下に述べる数值モデルは理解が得られやすいように, 後述する妥当性の検証のため模擬土壤を用いた実験との
比較を行った解析の系に基づいて説明を行うが, 数值モデ ルそのものは三次元への拡張, 任意の熱源位置, 形状, 境 界条件等に容易に適用可能である。図 1 に解析を行った系 を示す。系は四隅に直径 $d$ の凍結管が存在する二次元空間 で，境界に抢ける温度の対称性から，凍結管表面以外の 境界は断熱条件と同じに考えることができる。対称性から さらに, 凍結管 1 本分の空間（図 1 の 4 分の 1 の空間）を 解析する系とすることができるが,ここではモデルの適用 性を示すため図 1 のような形とした。系内は体積含水率 $\varepsilon$ の飽和含水土潩とし, 初期状態では温度, $T_{i}$ の液相とする (ここで言う液相, 固相とは, 土壌粒子間の水が液相か固 相かということを表し，土壤粒子そのものは変化しない)。 時刻, $t=0$ に打いて凍結管が水の凝固点よりも低い温度, $T_{w}$ に設定されることで土䁃の凍結が開始するものとする。 モデル化は次のような仮定に基づいて行った。

（1）対流は二次元で層流である。

(2)エネルギ式における粘性散逸は無視できる。

（3）流体（水）は非圧縮性で，ブジネスク近似が成り立つ。 (4) 運動方程式中の浮力に上る発生項を除き, 流体（固相 あるいは液相）の物性值は一定である。

(5) 固相（水）および土壤粒子は静止している。

(6) 水の固一液相変化に伴う密度変化は無視できる注1)。

以上のような条件·仮定に基づくと支配方程式は次のよ うに導出される。

連続の式

$$
\nabla \cdot \mathbf{u}=0
$$

運動方程式

$$
\rho \frac{\partial \mathbf{u}}{\partial t}+\rho(\mathbf{u} \cdot \nabla) \mathbf{u}=-\nabla p+\rho \nu_{\ell} \Delta \mathbf{u}-\frac{\nu_{\ell}}{\mathrm{K}\left(\gamma_{\ell}\right)} \mathbf{u}+\left(\rho_{r e f}-\rho\right) \mathbf{g}
$$

エネルギ式 (エンタルビ表示)

$$
\rho \frac{\partial h}{\partial t}+\rho \nabla \cdot\left(\mathbf{u} h_{\ell}\right)=\nabla \cdot(\lambda \nabla T)
$$

ここで, u は土壤を多孔質物質と考えたときの Darcy 速度 ベクトル， $t, p, \nu, \mathbf{g}, h$ はそれぞれ，時間，圧力，同粘 性係数，重力ベクトル，エンタルピを表す。また， $\rho, \lambda$

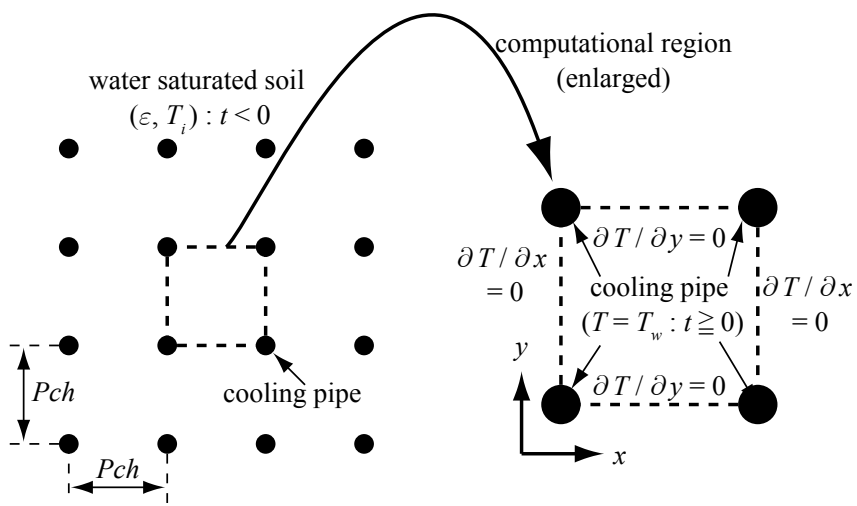

図 1 物理モデル

注 1) 本研究では温度場と凍土の予測を目的とし，凍上について は取り扱わない。水の場合, 固一液相変化に伴う体積変化 は約 $10 \%$ 程度で小さく，また，固一液相変化現象は緩慢で あるため。体積変化によって誘起される流体速度はほぼ無 視できる。 
および $\gamma_{\ell}$ の関数 $\mathrm{K} は$ は，それぞれ式 (3)，式 (6)，式 (9) で示される固相, 液相および土壤粒子を含む混合体の密 度, 熱伝導率, 浸透係数である。さらに, 下添え字 $\ell$, ref はそれぞれ混合体中の液相部分での值, 標準状態における 值を示している。

例えば水の場合, 相変化温度である $0^{\circ} \mathrm{C}$ の固相 (水) と 液相（水）の両方が存在しうるため, Single-domain model では温度だけではなくエンタルビを用いて, 式 (3) のよ うにエネルギ式は導出される。しかしながら,このままで は変数が増えてしまい解析がしづらいため, エンタルビ $h$ と温度 $T$ の関係と局所熱平衡の仮定を用いることで, 次の 温度表記のエネルギ式を用いる。

エネルギ式 (温度表示)

$$
\rho \frac{\partial T}{\partial t}+\rho c_{\ell}(\mathbf{u} \cdot \nabla) T=\nabla \cdot(\lambda \nabla T)-\rho_{\ell} h_{f} \frac{\partial \gamma_{\ell}}{\partial t}
$$

式（1）功式（3'）は, 相変化のない場合の一般的な 熱・物質移動の支配方程式に類似しているが, これらの式 は微小検査体積を固相, 液相, 土壤粒子の混合体であると 考え, それぞれの相で保存式を求め, それらを加えあわせ て平均化することにより導かれている。したがって,この 導出方法を用いると, 本研究のような含水土壤の凍結・融 解問題だけでなく, 多成分系水溶液の固一液相変化熱伝達 問題のような系内に任意の相が含まれる場合についても 解析が可能である。上式における密度, 比熱および熟伝導 率は, 混合体の物性值であり, 次のように定義される。

$$
\begin{aligned}
& \rho \equiv(1-\varepsilon) \rho_{p}+\left(\varepsilon-\gamma_{\ell}\right) \rho_{s}+\gamma_{\ell} \rho_{\ell} \\
& \rho c \equiv(1-\varepsilon) \rho_{p} c_{p}+\left(\varepsilon-\gamma_{\ell}\right) \rho_{s} c_{s}+\gamma_{\ell} \rho_{\ell} c_{\ell} \\
& \lambda \equiv(1-\varepsilon) \lambda_{p}+\left(\varepsilon-\gamma_{\ell}\right) \lambda_{s}+\gamma_{\ell} \lambda_{\ell}
\end{aligned}
$$

ここで，添え字 $p, s$ および $\ell$ はそれぞれ土壤粒子，水 の固相, 液相での值を意味する。また, 上式中の速度べク トル $\mathbf{u}$ は,

$$
\mathbf{u} \equiv \frac{1}{\rho}\left[(1-\varepsilon) \rho_{p} \mathbf{u}_{p}+\left(\varepsilon-\gamma_{\ell}\right) \rho_{s} \mathbf{u}_{s}+\gamma_{\ell} \rho_{\ell} \mathbf{u}_{\ell}\right]
$$

と定義される混合体の平均速度 (Darcy 速度) で, 計算に 用いた仮定（3）〜（6）を用いると， $\mathbf{u}_{p}=\mathbf{u}_{s}=\mathbf{0}, \rho_{s}=\rho_{\ell}$ および $\rho_{\ell}$ は浮力項以外では一定の条件が成り立つため, 結 局， $\mathbf{u}$ は $\mathbf{u}_{\ell}$ を用いて次式のように表される。

$$
\mathbf{u}=\frac{\rho_{\ell} \gamma_{\ell}}{\rho} \mathbf{u}_{\ell}
$$

なお, 本研究の目的はモデルの導出とその妥当性の検証に あり.含水土壌の有効熱物性值について論ずるものではな いため, 計算上の煩雑さを避ける目的で局所体積含水率 $\gamma_{\ell}$ から一意に混合体の物性值を求めることができる, 式 (4) 〜（6）を用いた。

以上の支配方程式は, 各相の平均量に対する一般的な方 程式となっているだけなので, Multi-domain model のよう に固相と液相で区別して別々の式を解く必要がなく, 上記 のただ一組の基礎方程式を全領域で解けばよいことにな る。Single-domain model をただ用いるだけでは単に固相
と液相とを一組の基礎方程式で同時に扱うことができる だけであるが, 本研究のような含水土壤内の凍結・融解過 程では冷却されるに従って凍土が増え（固相の生成）さ さ らに温度・境界条件によっては融解, 再凍結などもあり得 るのでこれらを考慮しなければならない。水が凍結・融解 する場合には必ず凍結境界面近傍での潜熱の授受がある ため, 局所的な潜熱のやりとりを定式化する必要がある。 本研究では, この相変化に伴う潜熱の吸収・発生をエネル ギ式, 式 (3') の右辺第 2 項目の発生項の形で考慮するこ とで, 固一液相界面の位置について特別の配慮をする必要 がなくなる。初期体積含水率 $\varepsilon$ とは異なり, この項中の局 所体積含水率 $\gamma_{\ell}$ は計算の際の各検査体積における体積含 水率を表しており, 既知ではなく, 凍結または融解ととも に変化する変数として取り扱われる。この $\gamma_{\ell}$ は検査体積 における温度ーエンタルピの関係から, 相变化温度（凝固 点）を $T_{P H}$ とおけば,

$$
\gamma_{\ell}^{n+1}=\gamma_{\ell}^{n}+\frac{(\rho c)^{n}}{\rho_{\ell} h_{f}}\left(T^{n}-T_{P H}\right) \quad(n \text { は計算の反復回数 })
$$

i）上式で計算された $\gamma_{\ell}^{n+1}$ が $\gamma_{\ell}^{n+1}>\varepsilon$ の時, $\gamma_{\ell}^{n+1}=\varepsilon$

ii）上式で計算された $\gamma_{\ell}^{n+1}$ が $\gamma_{\ell}^{n+1}<0$ 時, $\gamma_{\ell}^{n+1}=0$ のように更新されるが ${ }^{14)}$, 式 (1) 〜 (3') と式 (8) は式 (4) 〜 (6) 等を通じて陰的に結合しているため, 同時間ス テップにおける反復計算が必要となり, 式（3'）と式（8） 間で局所的な陰的時間進行法が必要となる ${ }^{10) 13)}$ 。本研究の この手法を用いれば, 式 (1) 〜 (3') 以外に化学種の保 存式を立て, それぞれの化学種の濃度・温度関係（例えば 共晶系の状態線図など）を定式化し式（8）のように扱え ば析出現象や固 - 液共存層 (Mushy Region) の取り扱いも 容易に可能となる。

運動方程式, 式 (2) の右辺第 3 項の Darcy 項は普通は 多孔質層内における流動抵抗を表すが, 本研究では Darcy 項中の浸透係数 $\mathrm{K}$ を次のような $\gamma_{\ell}^{n+1}$ の関数と定義する。

$$
\mathrm{K}\left(\gamma_{\ell}\right) \equiv \frac{d_{p}^{2}}{180} \cdot \frac{\gamma_{\ell}^{3}}{\left(1-\gamma_{\ell}\right)^{2}}\left(d_{p} \text { は土壤粒子の平均粒径 }[\mathrm{m}]\right)(9)
$$

式（9）のように取り扱うことにより，土壤粒子間の水が 完全に液相の領域 $\left(\gamma_{\ell}=\varepsilon\right)$ では Carman - Kozeny の提案 した浸透係数 ${ }^{15)}$ に等しくなり,一方, 完全に固相の領域 $\left(\gamma_{\ell}\right.$ =0）で浸透係数 $\mathrm{K}$ は 0 になるため, 結果として Darcy 項 は無限大に近づき, 固相内での速度は 0 と自動的に計算 される。このように計算中には固相か液相かを意識する 必要は全くなく, 明確な境界面の位置を取り扱わないも のの，境界面位置を図示する場合などにおいて便宜上境 界面位置が必要な時には, 得られた液相体積割合の分布 を基にして, $\gamma_{\ell}=\varepsilon / 2$ となる点をトレースして固－液界 面位置（凍土境界面）とした。なお, 式（2）の右辺第 4 項は密度変化による浮力の項であるが, 水は凝固温度付 近で密度逆転の性質を有し, 外部からの地下水流のない 自然対流支配の場合には凝固・融解現象に非常に強い影

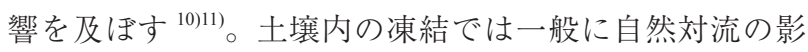
響は小さいと考えられるが，冷却（または加熱）期間が 
長い場合や土壤粒子が大きく粒子間の隙間が大きい場合 にはこれらの影響が無視できないと考え, 本研究におい ても密度逆転を考慮した水の温度 - 密度関係式 ${ }^{16)}$,

$$
\rho_{\ell}=\frac{1}{\left(1+\beta_{1} T+\beta_{2} T^{2}+\beta_{3} T^{3}+\beta_{4} T^{4}\right)}\left(\rho_{\ell}\right)_{T=0^{\circ} \mathrm{C}}
$$

定数 $\beta_{1}=-0.678964520 \times 10^{-4}\left[{ }^{\circ} \mathrm{C}^{-1}\right], \beta_{2}=0.907294338 \times 10^{-5}\left[{ }^{\circ} \mathrm{C}^{-2}\right]$

$\beta_{3}=-0.964568125 \times 10^{-7}\left[{ }^{\circ} \mathrm{C}^{-3}\right], \beta_{4}=0.873702983 \times 10^{-9}\left[{ }^{\circ} \mathrm{C}^{-4}\right]$ を用いて定式化を行った。それ以外の物性值は, 土壤粒子 および水（液相）は $\left(T_{i}+T_{P H}\right) / 2$ における值を, 水（固 相）には $\left(T_{w}+T_{P H}\right) / 2$ における值を用いた。

以上の基礎式は無次元化された後, 離散化されて MAC 法や SIMPLE 法などの数值解法で解かれることになるが, 式 (1) 〜 (3') はデカルト座標系に関するものであり,こ のままでは (冷) 熱源の位置や解析系の幾何形状が複雑な 場合に計算格子と境界とが一致せず, 補間の必要性や誤差 が生じる可能性がある。そのため, これらの式は一般座標 系に写像変換し, 解かれることになる。この基礎式の写像 変換に際しては, 物理空間と写像空間の格子座標を一対一 に対応させるために格子生成も必要となる。

\section{3. 数値モデルの妥当性の検証}

前章の数值モデルの妥当性を検証するため, 模擬土壌を 用いた凍結実験を行い, 実験で得られたデータと解析結果 とを比較検討した。実験装置は大きく分けて, 模擬土壤を 封入するテストセクションと, 土畩温度の等温維持または 凍結管温度設定用の恒温水槽とブライン循環管路, さらに 温度測定記録装置からなっている。図 2 にテストセクショ ンの概略図を示す。テストセクションは厚さ $15 \mathrm{~mm}$ のア クリル製矩形容器で, 内部には初期設定用および凍結用 のステンレス製伝熱管（内径 $5 \mathrm{~mm}$, 外径 $6 \mathrm{~mm}$ ) を 4 本 設置した。容器内部には, より実際の土壤に近づけるた め, 数種類の砂を混合したもの（主成分は珪砂: 平均粒径 $d_{p}=0.115 \times 10^{-3} \mathrm{~m}$, 密度 $\rho_{p}=2.80 \times 10^{3} \mathrm{~kg} / \mathrm{m}^{3}$, 定圧比熱 $c_{p}=$

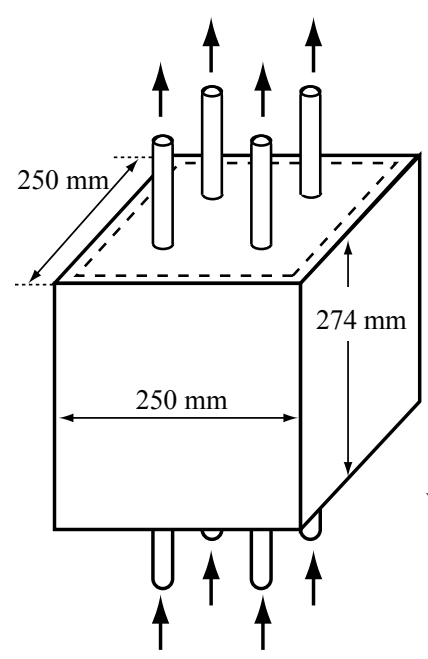

cooling pipes

(a) テストセクション全体

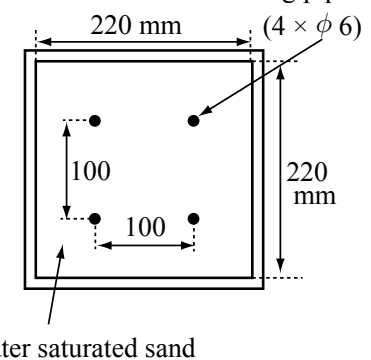

$0.922 \mathrm{~kJ} / \mathrm{kg} \cdot \mathrm{K}$, 熱伝導率 $\left.\lambda_{p}=3.49 \mathrm{~W} / \mathrm{m} \cdot \mathrm{K}\right)$ を水で締め固 めたものを封入し, 模擬飽和含水土壤とした。封入後の体 積含水率は $\varepsilon=0.365$ である。実験中はテストセクション全 体を厚さ $50 \mathrm{~mm}$ のスタイロフォーム製断熱材で周囲を囲 つて断熱し, 外部からの入熱の影響が最小限になるように した。土壤の温度は, 容器のほぼ中央の深さ位置 $132 \mathrm{~mm}$ で伝熱管からの距離の異なる 26 個の熱電対により定期的 に測定して温度および凍土分布を得た。また, それとは別 に恒温槽, 伝熱管入口・出口の温度測定も行い, 初期設定 または伝熱管温度が一定となるように調節した。実験で は, 含水土䁃全体があらかじめ決められた一様な初期温度 $T_{i}\left(=20.0 \pm 0.30{ }^{\circ} \mathrm{C}\right)$ になるまで伝熱管に流体を流し，そ の後, 恒温槽を切り替えて伝熱管を設定温度 $T_{w}(=-20.0$ $\left.{ }^{\circ} \mathrm{C}\right)$ に急変させることで凍結を開始した。伝熱管の設定温 度 $T_{w}$ は凍結開始直後の過渡期（5 分間未満）を除いて, ほ ぼ一定 $\left(T_{w}=20.0 \pm 0.30{ }^{\circ} \mathrm{C}\right)$ に保った。

一方, 数值解析では図 1 の物理モデルを図 3 のように格 子分割して行った。物理空間における格子形成は格子間隔 の粗密を容易に制御可能な Streger と Sorensonによる楕円 型方程式の数值解による方法 ${ }^{17)}$ で生成し, 計算格子数に ついてはいくつかのサイズのもので予備計算を行った。計 算格子数を増やすと精度は向上するが, 一方で計算時間や 必要記憶容量が増大するため, 本解析では $\xi \times \eta=69 \times 98$ とした。なお, 数值解法には MAC 法を用いて計算を行っ た。計算では先に述べたように同一時間ステップにおける 反復計算が必要なため, 収束条件を次のようにした。 凍結管外径 $d$ と液相の温度伝導率 $a_{\ell}\left(=\lambda_{\ell} /\left(\rho_{\ell} \cdot c_{\ell}\right)\right)$ を用 いて無次元化した無次元速度 $\mathbf{U}\left(=d \times \mathbf{u} / a_{\ell}\right)$ および無次 元圧力 $P\left(=d^{2} \times p /\left(\rho_{\ell} \times a_{\ell}^{2}\right)\right)$ に関して,

$$
\frac{\max \left|\phi^{n+1}(i, j)-\phi^{n}(i, j)\right|}{\max \left|\phi^{n+1}(i, j)\right|}<10^{-5} \quad(\phi \text { は } U, V \text { または } P)
$$

土壤初期温度 $T_{i}$ と伝熱管設定温度 $T_{w}$ を用いて無次元化し た無次元温度 $\theta\left(=\left(T-T_{i}\right) /\left(T_{w}-T_{i}\right)\right)$ および液相体積割合 $\gamma_{\ell}$ に関して,

$$
\max \left(\frac{\left|\phi^{n+1}(i, j)-\phi^{n}(i, j)\right|}{\left|\phi^{n+1}(i, j)\right|}\right)<10^{-5} \quad\left(\phi \text { は } \theta \text { または } \gamma_{\ell}\right)
$$

とした。また，無次元化した支配方程式に現れる無次元 数のうち, 重要なパラメータである Stephan 数, Rayleigh 数および Darcy 数は, 本計算条件の場合はそれぞれ Ste = $0.139, \mathrm{Ra}=4.60 \times 10^{3}$ および $\mathrm{Da}=2.53 \times 10^{-7}$ の值になる。 ここで, Stephan 数

$$
\mathrm{Ste} \equiv \frac{c_{s}\left(T_{P H}-T_{w}\right)}{h_{f}} \quad\left(h_{f} \text { は液相の凝固・融解潜熱 }\right)
$$

Rayleigh 数

$$
\operatorname{Ra} \equiv \operatorname{Gr} \times \operatorname{Pr}=\frac{g\left|\beta_{1}\right| d^{3}\left(T_{i}-T_{P H}\right)}{a_{\ell} \nu_{\ell}}
$$

(g は重力加速度, $\nu_{\ell}$ は液相の動粘性係数)

図 2 実験装置の概略図 
Darcy 数

$$
\mathrm{Da} \equiv \frac{\mathrm{K}(\varepsilon)}{d^{2}}=\frac{d_{p}^{2} \varepsilon^{3}}{175 d^{2}(1-\varepsilon)^{2}}
$$

と定義した注2)。

図 4 に凍結割合の時間変化を示す。図中の縦軸の凍結割 合は図 1 の物理モデル領域内の含水土塞がどれだけ凍結 したかを表す割合で, 数值計算では体積含水率 $\gamma_{\ell}$ の全領 域にわたる平均值を計算することで単純に求めることが できる。

$$
\text { solid volume ratio } \text { cal. }_{\text {. }}=\frac{\sum_{i=0}^{\text {all }}\left(V_{i} \times \gamma_{i}\right)}{\sum_{i=0}^{\text {all }} V_{i}}
$$

ここで, $V_{i}$ は各計算検査体積の体積, $\gamma_{\ell}$ は各計算検査体積 の体積含水率である。

一方, 実験では測定された温度場から凍土境界面位置に 換算して求められるが, 凍結現象では相変化温度 $\left(T_{P H}=0\right.$

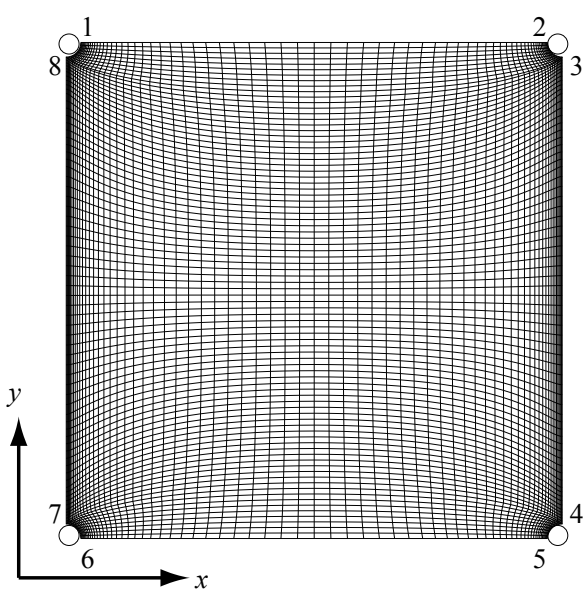

(a) 物理空間 $(x \times y=69 \times 98)$

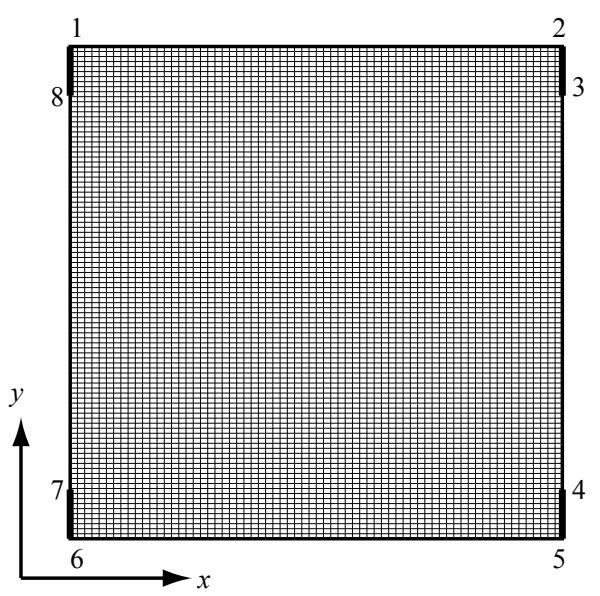

(b) 写像空間 $(\xi \times \eta=69 \times 98)$

図 3 計算格子

注 2）融解過程の場合は Stephan 数と Rayleigh 数はそれぞれ次の ように定義される。

Ste $\equiv \frac{c_{\ell}\left(T_{w}-T P H\right)}{h_{f}}, \quad \mathrm{Ra} \equiv \frac{g\left|\beta_{1}\right| d^{3}\left(T_{w}-T_{P H}\right)}{a_{\ell} \nu_{\ell}}$ $\left.{ }^{\circ} \mathrm{C}\right)$ 領域が潜熱分に相当して現れ，このまま， $0{ }^{\circ} \mathrm{C}$ の等温 線を凍土境界面としたのでは不正確さが生じるため， $T=$

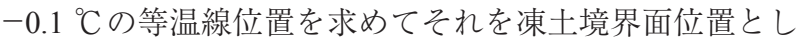
た。

$$
\text { solid volume ratio } \text { exp. }=\frac{V_{T \leq-0.1^{\circ} \mathrm{C}}}{V_{\text {total }}}
$$

ここで, $V_{\text {total }}$ は計算領域と同じ領域に相当するテストセク

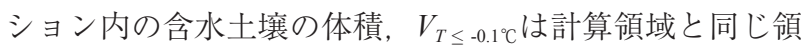
域に存在する温度が $-0.1{ }^{\circ} \mathrm{C}$ 以下の含水土䁃の体積である。

図より, 計算結果と実験で得られた結果は定性的にも定 量的にもよい一致を示していることが分かる。さらに図か らは計算值, 実験值とも凍結割合の時間変化傾向は大きく 分けて, 凍結初期 $(t<900 \mathrm{~s})$, 凍結中期 $(900 \mathrm{~s}<t<3600$ $\mathrm{s})$, 凍結後期 $(3600 \mathrm{~s}<t<10800 \mathrm{~s})$, 凍結末期 $(t>10800$ s）の 4 つの期間に分類できることも分かる。凍結初期に おいては, 単位時間当たりの凍結量すなわち凍結速度（図 4 の曲線の傾きに相当）は大きいが, すぐに凍結速度は遅 くなり頭打ちの傾向を示すような凍結中期に移行する。そ の後, 凍結後期では $3600 \mathrm{~s}$ 付近から凍結速度が急激に大 きくなり，長時間に渡って凍土が成長するが，すべての領 域が凍結完了する末期では, また徐々に凍結速度が小さく なっていく。

この現象を詳しく調べるために. 図 5 に計算で得られた 温度分布と凍土境界面位置の時間変化を示す。図中には実 験で得られた凍土境界面も示している。図より, 凍結割合 だけでなく凍土境界面も実験デー夕と計算結果とでは比 較的よい一致を示していることが分かる。凍結初期では (図 5 の $t=1800 \mathrm{~s}$ 参照), 凍結管近傍の土壤が急速に冷却 されて凍結するため, 一時的に凍結速度は大きくなる。一 方で凍結管から距離の遠い中央部付近では $10^{\circ} \mathrm{C}$ 付近の比 較的高温の領域が残っているため,この影響で凍結速度が 徐々に低下するようになる。なお, 実験によって求められ た凍土境界面と解析值は, 実験初期においてもっとも差が 大きくなっている。これは実験上の制約から, 凍結開始直 後に凍結管壁温を瞬間的に設定温度 $\left(-20.0{ }^{\circ} \mathrm{C}\right)$ に切り替 えることができないこと, その際に入り口と出口の温度差 が大きくなることに起因する。解析では実験で測定された 平均管壁温を凍結管温度として用いており，そのために誤 差が生じたと考えられる。したがって時間とともに実験で の凍結管温度が設定温度で安定し, 初期の影響が小さくな るにしたがって, 実験值と解析值との差は小さくなる。次

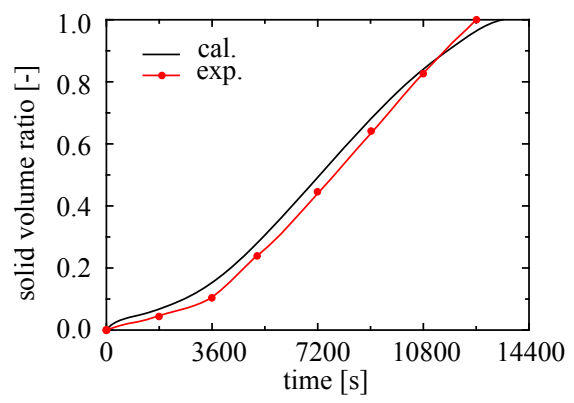

図 4 凍結割合の時間変化 


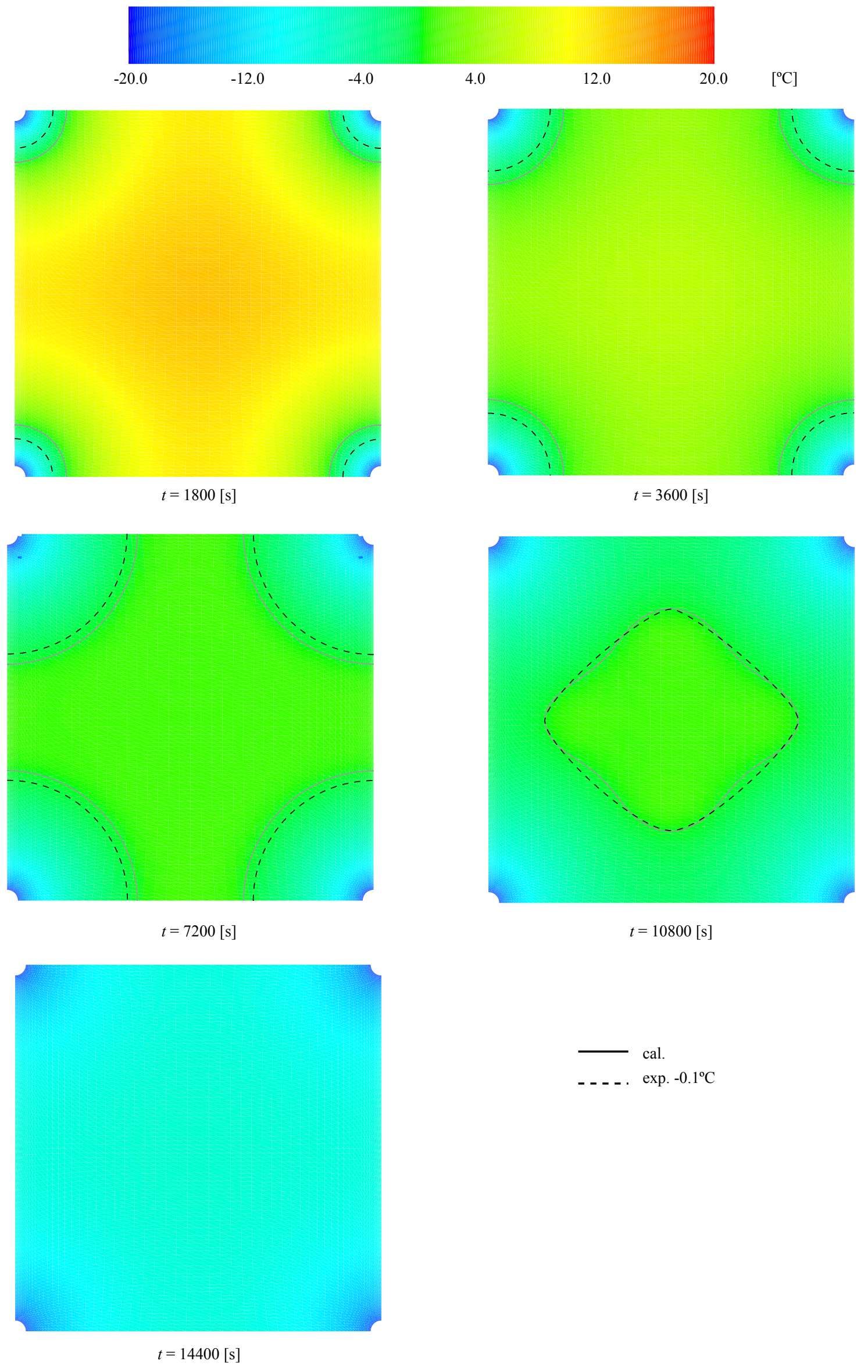

図 5 凍土境界面および温度分布の時間変化 
に, $t=3600 \mathrm{~s}$ の凍結中期をみると, 凍結初期の $t=1800 \mathrm{~s}$ の図と比べて凍土はあまり発達しておらず, 凍結速度その ものは遅くなっていることが分かる。しかしながら, 凍結 管からの冷却による顕熱の拡散が急速に進み, 中央部付 近でも相変化温度近くまで冷やされている。土壤の顕熱 分の冷却が進むと次の段階では急速に潜熱交換が行われ， 凍結後期（ $t=7200 \mathrm{~s}$ の図参照）では凍結速度が再び増加 し, 凍土が急速に拡大する。時間がより進み, それぞれ の凍結管からの凍土が連結するようになると（ $t=10800 \mathrm{~s}$ の図参照), 凍土内の冷却が進み, 未凍結部分での顕熱交 換が低下するため, 結果として実質的な凍土成長速度が見 かけ上低下する。したがって図 4 でも見られたように, 凍 結末期では凍結速度が徐々に小さくなる。水分を含まな い土壤粒子の温度伝導率 $a_{p}\left(=\lambda_{p} / \rho_{p} \cdot c_{p}\right)$ は水（液相）の 約 4 倍で温度の拡散が大きく, さらに水は 10 倍のオーダ 一であるため, 以上のように凍結層の少ない初期段階を除 いて凍土内部での顕熱分の熱交換がかなり早くなる。図 4 では凍結末期において, 解析結果 (図中の黒線) では凍結 速度の低下が顕著に表れているが, 実験結果より求めた值 (図中の赤線) ではあまり現れていない。これは凍土が成 長したため, テストセクション（図 2(a)）側壁の影響を受 けたためと考えられる。図には示していないが, 土壤初期 温度, 凍結管温度さらに土壤粒子を変えた条件での実験 ${ }^{1)}$ および解析結果は同様に良好な一致を示した。なお, 実験 結果と計算結果との間で生じているその他のわずかな不 一致は, 主に凍結管周りの局所的な含水率の不連続性や 実験装置の断熱の一部不備に由来すると考えられる。ま た,この系を対象とした土壤凍結では先に述べたように 4 つの凍結期間に分類できたが, 当然, 系の幾何形状, 凍結

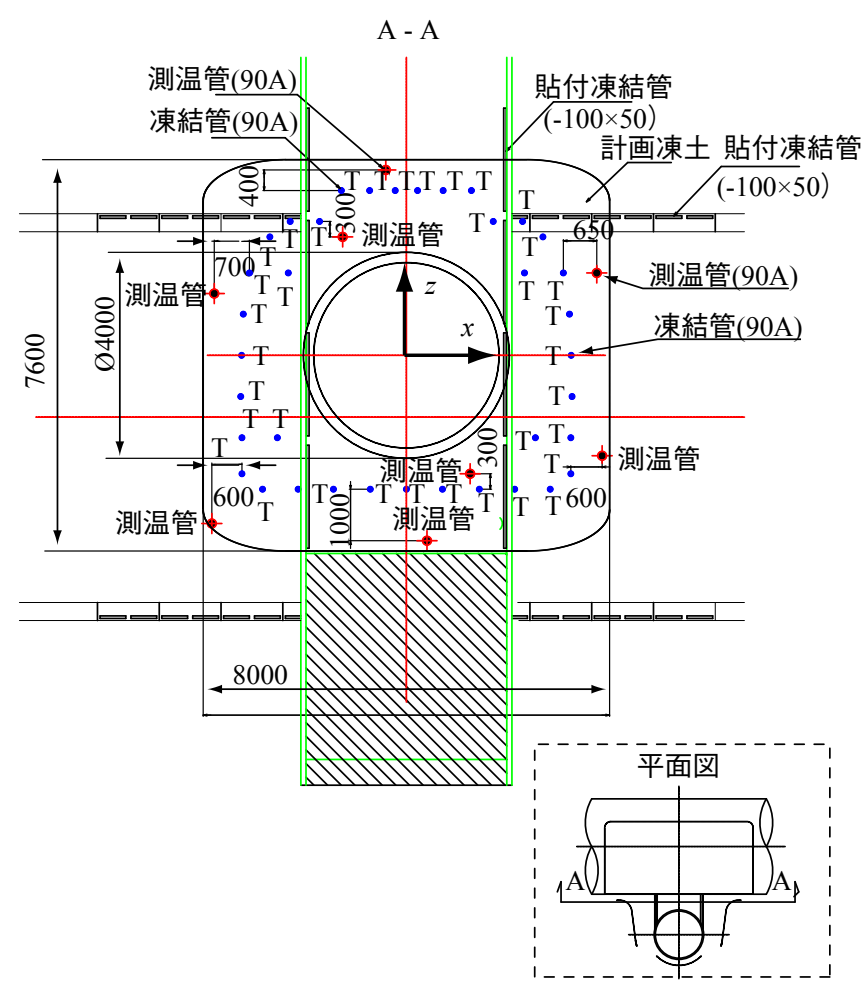

図 6 凍結管および測温管位置
管配置位置や温度条件によっては分類が異なったり，また は分類できない場合も考えられる。

次に, より大規模な事例に対する数值モデルの適応性を 検証するため, 実際に地盤凍結工法が用いられた施工現場 について数值解析を行い, その結果を現場での測温結果と 比較した。図 6 に凍結管, 測温管位置と計画凍土範囲を示 す。凍土は立坑と洞道とを接続する連絡洞道掘削時の保 護のために造成され, 地下約 $30 \mathrm{~m}$ の位置である。周辺の 土質は砂質泥岩で，凍結管および測温管として直径 101.6 mm（4 in.）の鋼管がそれぞれ 36 本，8 本敷設されている。 数值解析では, 図 6 中, A - A 断面の計画凍土範囲を中心 として縦 $17.2 \mathrm{~m}$, 横 $17.6 \mathrm{~m}$ の範囲を解析領域とした。数 值解法には SIMPLER 法を用いた。前述の模擬土壤を用い た実験との比較の際に用いた数值解法と異なる解法を用 いたのは, 種々の計算手法と本数值モデルとの適応性を検 証するためである。本数值モデルでは完全な固相と液相を 同じ支配方程式で解くが, 不自然に固相領域で速度が零に なるように変数を操作するやり方とは全く異なり, Darcy 項が変化することによって固相における速度場を自動的 に調整するため，凍土境界面近くの速度場，圧力場の不整 合·不連続性は全く生じることがなく，数值解法による影 響はなかった。

図 7 に 30 日後の凍土範囲の予測結果を示す。図より, 30 日後の時点で計画凍土範囲の凍結がほぼ完了しているこ とが分かる。実際の施工現場では測温管からの温度データ より凍土範囲を推測しなければならず，さらに，測温管埋 設には凍結管と同じコストが必要なため少ない本数で測 定し，予測しなければならないため，かなり安全率を見込 んだ凍土予測となり，実際には無駄に凍土を造成している 領域も多く生じていた。一方, 本計算手法では, 温度から 不正確に得られるのではなく, 液相の分布割合として凍土 範囲が得られるため非常に効率的で, 液相分布と同時に得 られる詳細な温度場, 速度場からの情報も役に立つことが 分かる。図 8 に計算で得られた温度変化と, 実際に測定さ れた温度データの比較を示す。図において, 記号

等)でプロットする温度は実際の施工現場にて測定され た温度で, 一方, 実線で示す温度は数值計算によって求め

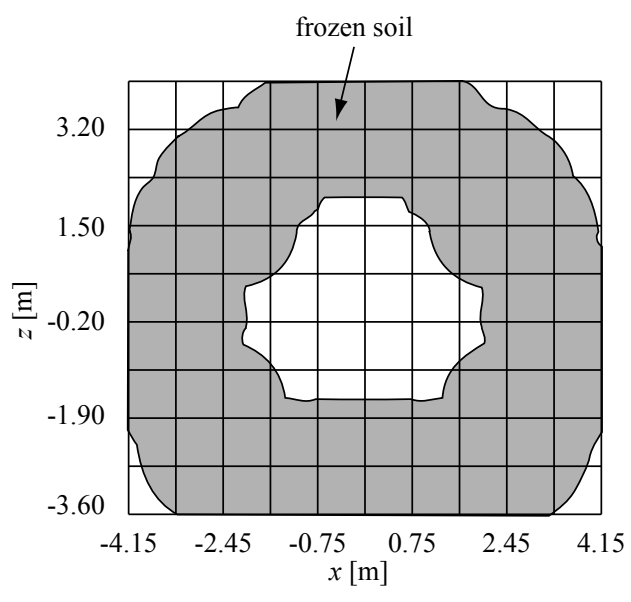

図 7 凍結開始 30 日後の予想凍土 


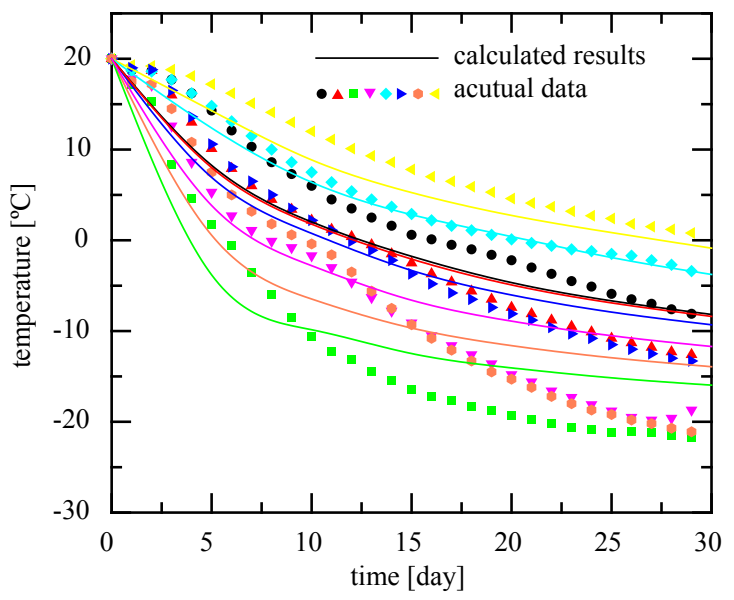

図 8 計算值と測温結果との比較

た值である。また, 記号と実線で同色のものは同じ位置の 温度であることを示している。図から, 両者はよい一致を 示し, 各場所の温度傾向を表していることが分かる。全体 的に計算值の方が実測值よりも低い温度となるのは，(1) 凍結管個々の表面温度の測定を行っていないため, ブライ ン槽入口および出口温度から得られた平均温度をすべて の凍結管温度として計算を行っているため, (2) 一般に実 際の施工現場では詳細な含水率分布を調べることが難し く, 本計算においては平均的な值を全領域に渡って用いた ため, (3) 一部の土壤中に不凍水が存在するためなどが考 えられる。上記に関連して, 凍結管は予定した冷却温度 （通常 $-20{ }^{\circ} \mathrm{C}$ 以下）にはすぐに到達せず, 凍結開始からお よそ 2 日〜一週間程度の日数を要するが, 解析的な解を求 める方法では, 境界条件である凍結管温度に変動值を入れ ることや局所の含水率分布を導入することは難しいが, 本 数值モデルの場合は, 初期条件として含水率分布（または 物性值の局所值）を与え, 各時間ステップの計算の際に境 界条件として凍結管温度を設定するだけなので取り扱い は非常に簡単である。図 8 において, 測定位置によっては 凍結開始 10 日目付近から徐々に冷却が進み, 実測值の方 が計算值よりも低い温度を示すようになるが（図中のロ,

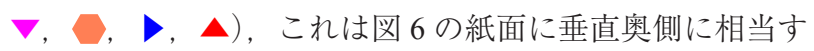
る位置で, 凍結の促進と凍土の維持を目的として平板状の 冷却を行っており.その影響が時間とともに現れたためと 考えられる。今回は数值モデルの適用性の検証目的であっ たため行わなかったが, 実際の施工時の計算ではあらかじ め計算しておいた結果との差から, 計算に使用する含水率 や境界条件の変化などのパラメータを再調節し, 再び計算 を行うことでより正確な結果が得られるようになる。

\section{4. 土䁃凍結・融解に及ぼす諸パラメータの影響}

数值モデルの妥当性が検証されたので, 次に含水率や温 度条件など代表的なパラメータが土畩凍結·融解現象に及 ぼす影響について調べた。なお, 凍結速度に及ぼす諸パラ メータの影響に関する実験結果は逢坂ら に詳述した。
図 9 に土壤の初期含水率が凍結現象に与える影響につ いて示す。数值計算は図 1 と同じ系で行い, 含水率以外の 条件（初期温度 $20^{\circ} \mathrm{C}$, 凍結管温度 $-20{ }^{\circ} \mathrm{C}$ ) も同じである (ただし, 凍結管温度はステップ变化とした)。図の縦軸は 図 4 と同じく凍結割合を示しており，横軸は無次元時間 $\tau\left(=a_{\ell} \bullet t / d^{2}\right)$ を表す。なお, 図 1 の計算領域は同一水平 面内の二次元領域であるため, 温度差に起因する浮力を含 まない計算に相当する。さて, 図から, 含水率が凍結割合 に大きく影響を与えることが分かる。凍結初期 $(\tau<10)$ では含水率による影響は見られないものの，それ以降の 時刻では含水率により凍結速度に顕著な違いが現れる。 この $\tau>10$ における凍結速度（=図中の曲線の傾き）は, それぞれの含水土潩の温度伝導率に比例し, 含水率が小さ いほど凍結速度は速くなる。ただし含水率が小さければ, 含水土壌単位体積当たりに含まれる凍結しなければなら ない水の体積が少ないため, より早く凍結するのは当然で, 凍結完了に要する時間（図の凍結割合が 1 に到達するま での時間）は, $\varepsilon=0.300 \rightarrow \varepsilon=0.400 （ 1.3$ 倍）と増加した 場合で 1.3 倍, $\varepsilon=0.300 \rightarrow \varepsilon=0.500$ (1.7 倍) と増加した 場合では 1.6 倍と,ほほ含水率に比例して長くなる。しかし ながら, 同一時刻における凍結割合の值を比較すると, 例えば $\tau=30$ のときに, $\varepsilon=0.300 \rightarrow \varepsilon=0.400$ で $1 / 1.4$ 倍, $\varepsilon=0.300 \rightarrow \varepsilon=0.500$ では $1 / 1.9$ 倍, さらに $\varepsilon=0.300 \rightarrow$ $\varepsilon=1.000$ (3.3 倍) と変化すると凍結割合は $1 / 4.2$ 倍になり, 含水率比の逆数よりも小さくなる。これは 3 章でも述べた ように, 図1のような凍結管に囲まれた領域の凍結現象は, (1)凍結管近傍の凍結, (2) 冷熱の伝播(顕熱分), (3) 凍土の 成長というプロセスで進むため, 凍結過渡期においては (2)の伝熱過程が大きく影響する。このことは上述の凍結 割合の比が含水土壤の有効熱伝導率 $(=$ 式 (6))の比に近い ことからも明らかである $(\varepsilon=0.300$ の時の有効熱伝導率を 1 とすると, $\varepsilon=0.400,0.500$ および 1.000 の時の有効熱 伝導率はそれぞれおよそ $1 / 1.1 ， 1 / 1.3$ および $1 / 4.5$ になる)。 したがって, 本研究のように土壤粒子の熱伝導率（および 温度伝導率）が水の值に比べて大きい場合には, 含水率が 小さいことで水の体積が減ることと伝熱促進効果のある 土壤粒子が増えることの二重の効果があることになる。

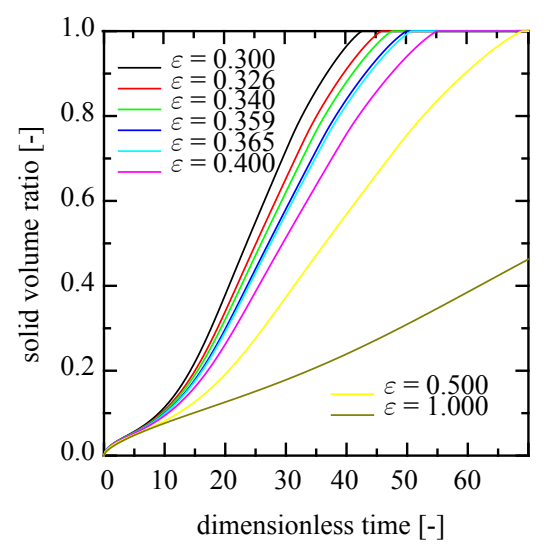

図 9 含水率の影響 
次に初期温度および冷却温度の影響について調べるた め, 冷却温度が $-20{ }^{\circ} \mathrm{C}$ で初期温度（凍結温度までの初期 過熱度）を $20,12,8$ および $4{ }^{\circ} \mathrm{C} に$ 変えた計算と, 初期温 度が $20{ }^{\circ} \mathrm{C}$ で泠却温度を -20 および $-10{ }^{\circ} \mathrm{C}$ 変化させた 条件の計算を行った。眓 10 に凝固割合の時間変化を示す。 図より初期温度が低いほど凍結速度は大きく, 冷却温度が 高いほど凍結は遅くなることが分かる。特に冷却温度の 影響は大きく, 同一初期温度で泠却温度の異なる, $T_{i}=20$ ${ }^{\circ} \mathrm{C}$ で $T_{w}=-20{ }^{\circ} \mathrm{C}$ と $-10{ }^{\circ} \mathrm{C}$ のつの場合を比較すると, $T_{w}$ $=-10{ }^{\circ} \mathrm{C}$ の場合の方は $T_{w}=-20{ }^{\circ} \mathrm{C}$ の場合に比べて Stephan 数が 2 分の 1 しかなく, 凍結初期の $\tau<5$ や $T_{w}=-20{ }^{\circ} \mathrm{C}$ の 場合に凍結速度が低下する $\tau>45$ の期間を除けば凍結量 は半分にも満たない。一方, 初期温度の違いは冷却温度ほ ど凍結割合に影響はしないが, 初期温度が高くなるほど凍 結初期において凍結速度が低下する傾向が見られる。ま た, この凍結速度低下は初期温度が高いほど, 冷却温度が 高いほど長くなる。これは先に述べたように, 初期温度が 高いほど, 冷却温度が高いほど, 顕熱分の除去（冷熱の 伝播）プロセスに時間を要するためである。初期温度の 大きさは無次元相変化温度 $\left(\theta_{P H}=\left(T_{P H}-T_{i}\right) /\left(T_{w}-T_{i}\right)\right)$ の 大きさとして整理することができ, 凍結割合はほほ $\theta_{P H}$ の 平方根に逆比例して変化する。表1に各計算条件における Stephan 数および $\theta_{P H}$ の值を示す。Stephan 数は式 (13) で 定義される潜熱と凍結後の（凍土部分の）顕熱の比であ り, Stephan 数が大きいほど冷却が強いことになり, 凍結 の早さを示す指標となる。Stephan 数だけでは冷却の強さ を示すだけで, 初期温度から凍結温度までの初期過熱度の 大きさが含まれておらず,一方で無次元相変化温度だけで は初期過熱度の大きさだけが含まれるため, ここで泠却の 強さと初期過熱度の大きさの両方を含む指数, $\mathrm{Ste} / \theta_{P H}^{1 / 2}$ を 導入する。図 10 中の右縦目盛りに $\tau=30$ における $T_{i}=20$ ${ }^{\circ} \mathrm{C}, T_{w}=-20{ }^{\circ} \mathrm{C}$ の時の凍結割合を 1 としたときの各温度条 件の Ste $/ \theta_{P H}^{1 / 2}$ の比を示す。これより $\tau=30$ の時の各温度条 件での凍結割合の関係は, 右軸に示した Ste $/ \theta_{P H}^{1 / 2}$ の比に近 い值になることが分かる。ほかの無次元時間においても, 時間ごとの Ste $/ \theta_{P H}^{1 / 2}$ の比に近い值で凍結割合が推移してい る。なお, $T_{i}=4{ }^{\circ} \mathrm{C}, T_{w}=-20{ }^{\circ} \mathrm{C}$ の場合には Ste $/ \theta_{P H}^{1 / 2}$ の比よ

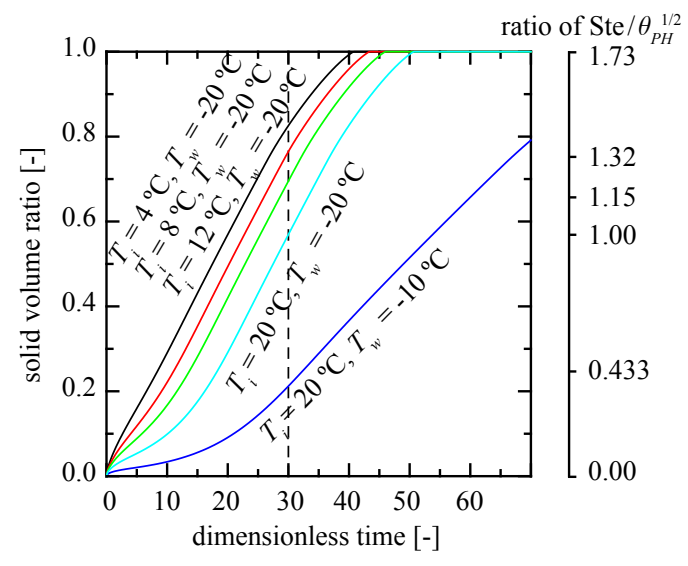

図 10 初期温度および冷却温度の影響
りも凍結割合が小さくなるのは, この温度条件では初期過 熱度が小さく, 未凍結領域よりも凍結領域の熱伝導が凍結 速度に支配的であるためと考えられる。

表 1 Ste および $\theta_{P H}$ の值

\begin{tabular}{c|c|c|c|c|c}
\hline$T_{i}\left[{ }^{\circ} \mathrm{C}\right]$ & $T_{w}\left[{ }^{\circ} \mathrm{C}\right]$ & Ste & $\theta_{P H}$ & Ste $/ \theta_{P H}^{1 / 2}$ & ratio* \\
\hline 4.0 & -20 & 0.139 & 0.167 & 0.341 & 1.73 \\
8.0 & -20 & 0.139 & 0.286 & 0.261 & 1.32 \\
12.0 & -20 & 0.139 & 0.375 & 0.228 & 1.15 \\
20.0 & -20 & 0.139 & 0.500 & 0.197 & 1.00 \\
20.0 & -10 & 0.070 & 0.667 & 0.085 & 0.433 \\
\hline \multicolumn{6}{c}{$* T_{i}=20{ }^{\circ} \mathrm{C}, T_{w}=-20{ }^{\circ} \mathrm{C}$ の Ste $/ \theta_{P H}^{1 / 2}$ を 1 としたときの比 }
\end{tabular}

次に, 凍結と融解が連続して生じる過程について数值解 析を行った。図 11 に計算を行った系を示す。計算領域は 直径 $d$ の伝熱管がピッチ $5 d$ で正方に配列された空間の一 要素 $(5 d \times 5 d)$ に相当する（重力の影響は無視する）。含 水率, 初期温度はいずれの場合もそれぞれ $\varepsilon=0.365$ およ び $T_{i}=20^{\circ} \mathrm{C}$ とし, 冷却温度は $-20{ }^{\circ} \mathrm{Cまたは}-10{ }^{\circ} \mathrm{C}$, 加熱 温度は $20{ }^{\circ} \mathrm{C}$ まな $10{ }^{\circ} \mathrm{C}$ とた。 $\tau=0.0 \sim 23.0$ を冷却過 程, $\tau=23.0$ 以降を加熱過程とした。なお， $\tau=23.0$ は, 凍 結工法に用いられる標準的な伝熱管（直径 $101.6 \mathrm{~mm}$ ) の 場合では，実時間で 20 日間に相当する。まず，図 12 に 凍結・融解割合の時間変化を示す。図において冷却温度 が $-20{ }^{\circ} \mathrm{C}$ で加熱温度が $20{ }^{\circ} \mathrm{C}$ と $10{ }^{\circ} \mathrm{C}$ の場合は冷却条件が 全く同じであるため冷却過程では全く同一の值を示す (冷 却過程において図中の赤線と黒線が重なる)。冷却温度が $-10{ }^{\circ} \mathrm{C}$ で加熱温度が $20{ }^{\circ} \mathrm{C}$ と $10{ }^{\circ} \mathrm{C}$ の場合（図中の青線と 緑線）も同様である。図より, 冷却温度が $-10{ }^{\circ} \mathrm{C}$ の場合 は凍結期間終了時でも完全に凍結には至らず, 未凍結領域 が約 1 割程度残ることが分かる。また, 冷却開始時 $(\tau=$ 0.0) では初期状態で均一な温度分布であるが, 加熱開始 時 $(\tau=23.0)$ には温度分布が存在するため初期条件が若干 異なるものの, 曲線の傾きから冷却過程に比べて加熱過程 の方が緩慢であることも明らかである。例えば $20{ }^{\circ} \mathrm{C}$ から

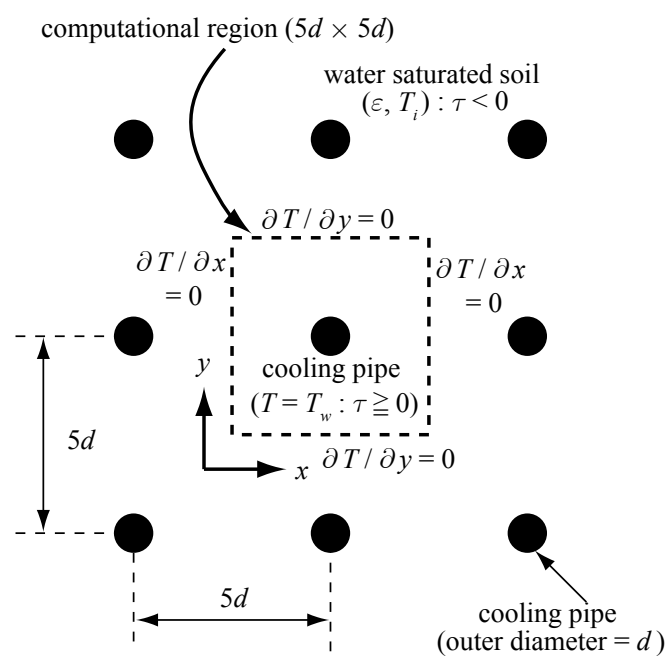

図 11 計算領域 


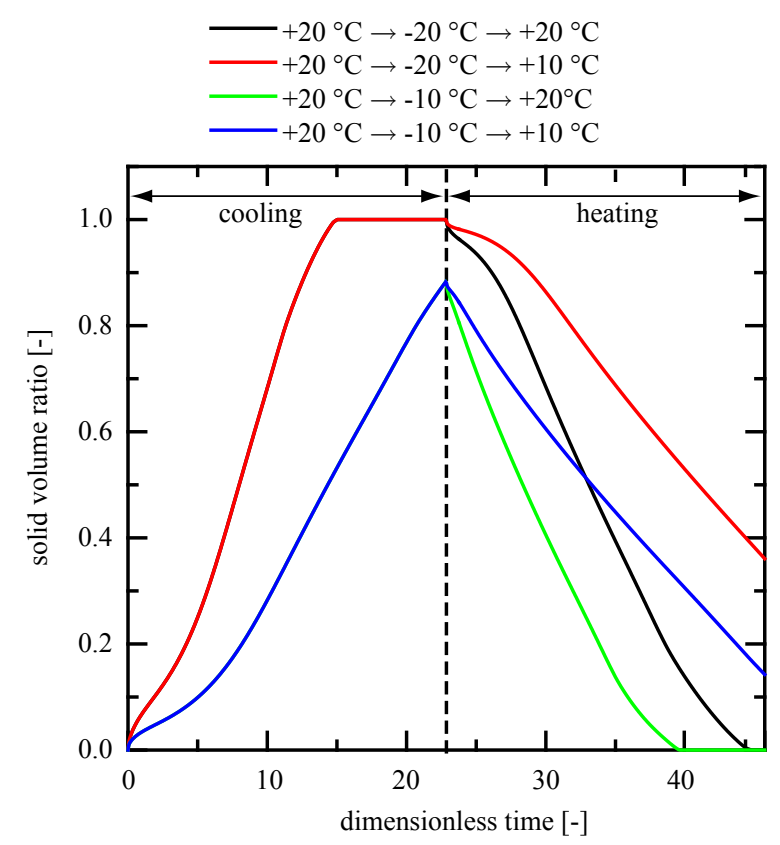

図 12 凍結および融解割合の時間変化

$-20{ }^{\circ} \mathrm{C}$ に冷却, $-20{ }^{\circ} \mathrm{C}$ から $20{ }^{\circ} \mathrm{C} へ の$ 加熱の場合（図中の 黑線), 冷却過程と加熱過程の温度差は等しくなるが, 先 に述べたように水 (液相) の方が氷よりも温度伝導率が小 さいため, 伝熱管の周囲を凍結層が取り巻く冷却過程に比 ベて, 伝熱管周囲に（凍結層よりも）温度伝播しにくい融 解層が生じる加熱過程の方が全体として熱の伝わりが悪 くなるためである。これにより, 加熱過程中に伝熱管周囲 には冷却過程より大きな温度勾配が生じる $(\tau=35$ におけ る凍土・融解層および温度分布, 図 13 , 参照)。また, 冷 却温度が $-10{ }^{\circ} \mathrm{C}$ の場合には計算対象領域が完全に凍結す る前に加熱過程が開始するため, 凍土境界面は図 13(a)や 13(b)にみられるように複雑な形となり, 冷却期間を終了 して融解が開始する際に残っている未凍結領域の影響を 受ける。しかしながら凍土境界面形状とは異なり, 温度分 布はほぼ同心円状になることが図からわかる。一方, 冷却 温度が $-20{ }^{\circ} \mathrm{C}$ の場合では, 計算対象領域が完全に凍結し
た後に加熱過程が開始するため凍土境界面, 温度分布とも に伝熱管周りにほぼ同心円状になって進行する（図 13(c) および (d) 参照)。

\section{5. まとめ}

系の幾何形状や境界条件が複雑な系にも適用可能で取 り扱いが簡易な含水土壤内の熱・物質移動数值モデルの構 築を行った。この数值モデルを用いた計算結果を実験結果 と比較・検討することによりモデルの妥当性を検証した。 また, 含水率や温度条件を変えた一連の数值計算を行いそ れらのパラメータが土壤の凍結や融解現象に及ぼす影響 について検討を行った。得られた結果をまとめると以下の ようになる。

1）導出した数值モデルはMAC 法や SIMPLER 法などの 数值解法と適応性がよく, このモデルを用いた計算結 果は, 模擬土壤を用いた実験結果および実際の地盤凍 結工法の施工現場での測温結果とよく一致し, 数值モ デルが妥当性であることが証明された。

2）複数管周りの土壤の凍結現象は大きく分けて, 凍結速 度が大きい凍結初期, 時間とともに徐々に凍結速度が 低下する凍結中期, 急速に凍結が進む凍結後期, 再び 凍結速度が低下する凍結末期に分類できる。

3）含水率の変化は含水土壤の温度伝導率の変化に直接 関係するため凍結速度への影響が大きい。また, 土 壤初期温度よりも冷却温度が凍結速度に及ぼす影響 の方が強く, 冷却の強さ, 凍結のしやすさはStephan 数と無次元相変化温度を用いて整理できることがわ かった。

4）凍結と融解が連続して生じる系では, 凍土境界面は加 熱開始時に残存する未凍結土の影響を強く受ける。

今後さらにこの数值モデルを用いた解析により, 含水率 や初期温度 · 冷却温度以外のパラメー夕, 例えば凍結管 ピッチ, 凍結管温度の変動などが土壇凍結に及ぼす影響に

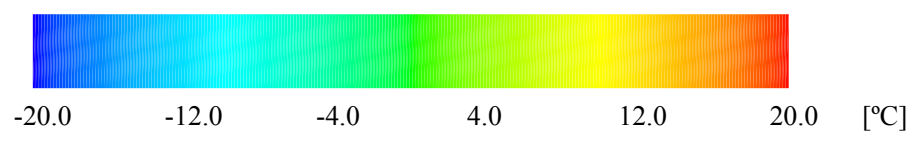

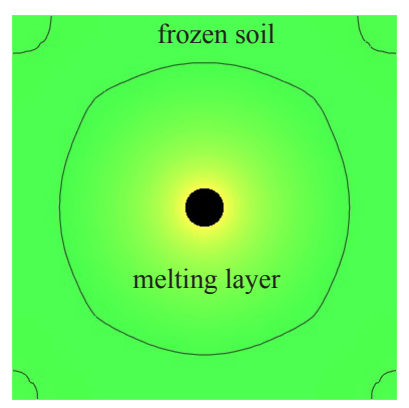

(a) $-10{ }^{\circ} \mathrm{C}$ 凍結, $+10{ }^{\circ} \mathrm{C}$ 融解

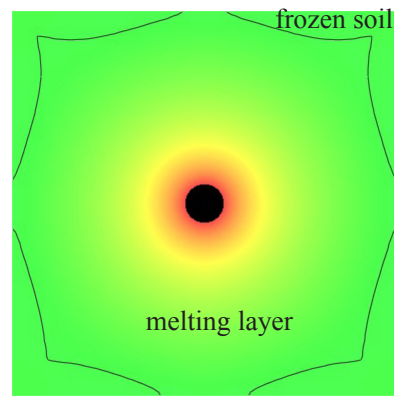

(b) $-10{ }^{\circ} \mathrm{C}$ 凍結, $+20{ }^{\circ} \mathrm{C}$ 融解

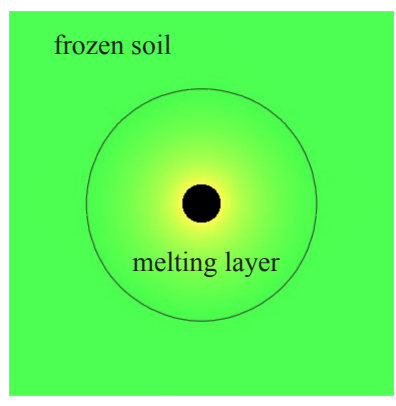

(c) $-20{ }^{\circ} \mathrm{C}$ 凍結, $+10{ }^{\circ} \mathrm{C}$ 融解

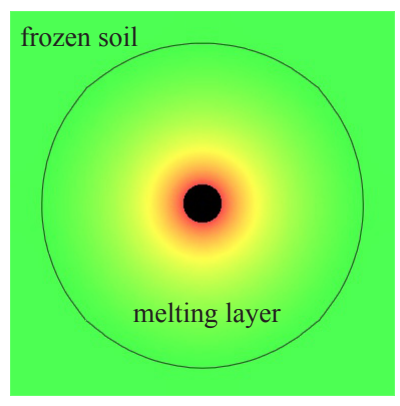

(d) $-20{ }^{\circ} \mathrm{C}$ 凍結, $+20{ }^{\circ} \mathrm{C}$ 融解

図 $13 \tau=35$ における凍土・融解層および温度分布 $\left(T_{i}=20{ }^{\circ} \mathrm{C}\right)$ 
ついて明らかにすることで, 地盤凍結工法時の凍結管の 最適配置，温度制御技術の確立につながると思われる。

\section{参 考 文 献}

1) 逢坂昭治, 草野剛嗣, 相馬啓, 横尾充, 堀井清之, 「含水土壤 内の円筒周りの凍結 一種々のパラメータが凍結速度に及ぼ す影響一」, 地盤工学ジャーナル, Vol. 3, No. 2, pp. 143-151, (2008).

2) 伊豆田久雄, 譽田孝宏「土の凍結と地盤工学 9. 地盤凍結 工法」土と基礎, Vol. 51, No. 11, pp. 63-68 (2003).

3) 地盤工学会, 講座「土の凍結と地盤工学」, 土と基礎, Vol. 51, No. $4 \sim$ Vol. 52, No. 3, (2003 2004).

4) 地盤工学会, 講座「移流分散解析入門」, 土と基礎, Vol. 50 , No. $9 \sim$ Vol. 51, No. 9. (2002 2003).

5) Hashemi, H. T. and Sliepcevich, C. M., "Effect of seepage stream on artificial soil freezlng", Journal of the Soil Mechanics and Foundations Division, Vol. 99, No. 33, pp. 267-289, (1973).

6) Holden, J. T., "Improved thermal computations for artificially frozen shaft excavations", Journal of Geotechnical and Geoenvironmental Engineering, Vol. 123, No. 8, pp. 696-701, (1997).

7) Lackner, R., Amon, A. and Lagger, H.,"Artificial ground freezing of fully saturated soil : thermal problem", Journal of Engineering Mechanics, Vol. 131, No. 2, pp. 211-220, (2005).

8) Watanabe, O. and Tanaka, M., "Thermal analysis of the positionof the freezing front around an inground LNG storage tank with a heat barrier", Proceedings of the 3rd International Symposium on Ground Freezing, pp. 177-184, (1982).

9) 後藤貞雄, 田中益弘, 「土の凍結と地盤工学 10. LNG 地下夕 ンク周辺地盤の凍結制御」, 土と基礎, Vol. 51, No. 12, pp. 86-91 (2003).
10) Sasaguchi, K., Kusano, K. and Viskanta, R., 1997, "A numerical analysis of solid-liquid phase change heat transfer around a single and two horizontal, Vertically spaced cylinders in a rectangular cavity", InternationalJournal of Heat and Mass Transfer, Vol. 40, No. 6, pp. 1344-1354, (1997).

11) Sasaguchi, K. Kusano, K., Kitagawa, H. and Kuwahara, K., "Effect of density inversion on cooling of water around a cylinder in a rectangular cavity", Numerical Heat Transfer, Vol. 32, pp. 131-148, (1997).

12) Kusano, K., Sasaguchi, K., Baba, Y., Hirota, T. and Ousaka, A., "Solid/liquid phase change heat transfer of a low concentration aqueous solution around horizontal cylinder(s) in a rectangular cavity", Proceedings of the 6th ASME - JSME Thermal Engineering Joint Conference, CD-ROM, TED-AJ03-308, (2003).

13）笹口健吾, 「固一液相変化を伴う系の熱移動および流動解 析」, 機械の研究, Vol. 46, No. 9, pp. 931-939, (1994).

14) Voller, V. R., Cross, M. and Markatos, N. C., "An enthalpy method for convection/diffusion phase-change", International Journal for Numerical Methods in Engineerlng, Vol. 24, No. 1, pp. 271-284, (1987).

15) Nield, D. A. and Bejan, A., "Convection in porous media, 3rd edition", Springer, pp. 6-7, (2006).

16) 藤井哲, 片山功蔵, 斎藤涁夫, 服部賢, 戸田三朗, 「伝熱工 学の進展第 3 巻」, 養賢堂, pp. 66, (1974).

17) Steger, J. L. and Sorenson, R. L., "Automatic mesh-point clustering neara boundary in grid generation with elliptic partial differential equations", Journal of Computational Physics, Vol. 33, No. 3, pp. 405-410, (1979).

(2007.6.14 受付) 
Prediction of frozen soil layer and temperature profile in water saturated soil —Numerical analysis on the heat transfer problem including freezing and/or thawing of soil-

\author{
Koji KUSANO ${ }^{1}$, Akiharu OUSAKA ${ }^{1}$, Hiroshi SOUMA² and Kiyoshi HORII ${ }^{3}$ \\ 1 Energy System, Institute of Technology and Science, The University of Tokushima \\ 2 Engineering Development Department, Chemical Grouting Co., Ltd. \\ 3 School of Liberal Arts, Shirayuri College
}

\begin{abstract}
It is very difficult to estimate transient freezing volume or completion time on artificial ground freezing (AGF), because the analysis depends on many thermal and physical conditions. The aim of this study is to establish the numerical model for the solidification or melting of water saturated soil and to clarify the effect of thermal and physical parameters, such as water content, initial and cooling temperature, on the artificial soil freezing. This numerical model can analyze the region which has multiple heat sources and sinks, diverse local thermal properties with/without ground water stream. From the numerical results, it was found that the initial water contents and cooling temperature affect the transient tendency of soil solidification. After connecting the solidified layers from each cooling tubes, the freezing rate decreases gradually. The knowledge obtained from this study will be useful to predict solid volume, decrease of necessary energy and minimize the influence to ambience on artificial ground freezing precisely.
\end{abstract}

Key words : numerical analysis, frozen soil, heat, saturated soil, water content, freezing rate, cooling temperature, initial temperature 